\title{
The Slavonic Third-Person Singular and Byelorussian Historical Dialectology: Some Tentative Observations
}

BY

\author{
RAYMOND H. MILLER
}

One of the most hotly-debated topics in all of Slavonic linguistics is the history of the third-person present-tense [hereafter 3pers] endings of firstand second-conjugation [1conj and 2conj] verbs. ${ }^{1}$ The variety of forms found in modern dialects, the enigmatic evidence of the old manuscripts, and the contradictory data from other Indo-European languages makes for a riddle that may never be solved.

This is not the place to write the ultimate solution to this problem. The issues involved are too many, and thus existing literature much too copious to review. ${ }^{2}$ The aim of this article is more modest: to shed some light on one facet of the problem - the third-person singular [3s] of 1conj verbs - by reviewing the evidence of Byelorussian dialects. In the course of this review, it will be seen that this material in turn illuminates yet another controversial topic in Slavonic linguistics: East Slavonic historical dialectology and the formation of the Byelorussian language.

\section{The Data}

In this section we will review the relevant data from the Old Russian manuscript tradition and from contemporary East Slavonic dialects. Although occasional reference will be made to other 3pers forms, we shall be focussing on the 1conj $3 \mathrm{~s}^{3}{ }^{3}$

In the old documents from the Kievan period until the 14th century, all 1 conj and 2conj verbs used, for the most part, 3pers desinences which ended in a soft $-t^{\prime}$ (orthographic - $t \grave{\imath}$ ). Endings with zero (Ø) that is, no - $t$ - element at all - can be found in all Old Russian manuscripts (some contain more than others). ${ }^{4}$ More $\varnothing$ forms occur in the 1 conj 3s than in any other 3pers form..$^{5}$

Modern East Slavonic dialects show the following distributions. In standard Ukrainian, as well as in most Ukrainian dialects, we see $\varnothing$ in the 1 conj 3s, and soft $-t^{\prime}$ in other 3pers forms. 1conj 3s -et' can be found in scattered SE and SW dialects. ${ }^{6}$

West Russian dialects centred roughly around Smolensk, as well as various systems southeast of Moscow around Tambov, have soft ${ }^{\prime} t^{\prime}$ in all four 3pers forms. $\varnothing$ in the 1conj $3 \mathrm{~s}$ is a feature of $\mathrm{NW}$ dialects in the vicinity, and to the northeast, of Novgorod and Pskov, and also of South Russian dialects spoken over an area which extends from just south of Moscow to the Ukrainian frontier. ${ }^{7}$ In standard Russian, as 
well as in Northern and East-Central dialects, all 3pers desinences display a hard $-t$, which is clearly a relatively late innovation. ${ }^{8}$ For the purpose of this study, it will be assumed that all these dialects originally had a soft $-t^{\prime}$ in all these forms - including the 1 conj $3 \mathrm{~s}$.

Standard Byelorussian has the same situation as standard Ukrainian: 1 conj $3 \mathrm{~s}$ in $\emptyset$, other 3pers forms in soft $t^{\prime}$ (which is realized, of course, phonetically as [-ć]. This same picture also obtains in the SW dialect group. Throughout the NE dialect area, all 3pers forms end in $\mid-t^{\prime} /\left[-c^{\prime}\right]^{9}$

The problem that linguists have been grappling with for decades is: which 3pers ending did Slavonic inherit from Indo-European? Both -ti and $\varnothing$ can be reasonably well established for the proto-language as 3 pers morphemes, but it is still hardly clear what was the $3 \mathrm{~s}$ ending of the Indo-European thematic conjugation - the prototype of the Slavonic first conjugation. ${ }^{10}$

Slavists, then, are divided as to what Common Slavonic had for 3 pers endings. Most investigators posit one basic system for Common Slavonic, which was later modified in individual dialects: (i) $-t \grave{\imath}$ in all four forms; later lost in some categories in most modern dialects; ${ }^{11}$ (ii) $\emptyset$ in all four forms; -t $t \grave{i}$ subsequently added in certain categories in some languages; ${ }^{12}$ or (iii) $\varnothing$ definitely in the 1 conj $3 s$, $-t \grave{\imath}$ in at least some other forms. ${ }^{13}$

Curiously, no one has yet seriously considered whether or not the variation we have in the modern languages goes back to a dialectal opposition in Common Slavonic. Henryk Birnbaum is the only author consulted who even brings up this possibility, and he rejects it out of hand. ${ }^{14}$ However, some East Slavonic specialists, after closely reviewing the evidence of the Old Russian manuscripts, have tentatively set up a dialect split for the Old Russian period: a 'basic' region over which 1 conj $3 \mathrm{~s}$ in $\emptyset$ was found, versus a NE area which displayed 1conj $3 \mathrm{~s}$ in $-t \bar{\imath} /-t^{\prime} .{ }^{15}$ We will see below that these scholars are more nearly right than Birnbaum.

\section{Modern Byelorussian and Russian Dialects: The Case for the Antiquity of $\varnothing$}

The data we have suggest strongly that the 1 conj 3s opposition of $\emptyset$ : $-t^{\prime}$ is indeed quite old, and that the ending -et' represents an innovation of the early historical period.

First, consider the NE Byelorussian dialects which display instances of $\varnothing$ alongside $-t^{\prime}$. In many cases, the only 1 conj verbs which can take $\varnothing$ are može and budze ${ }^{16}$ može 'is able' is frequently used adverbially in the meaning of 'maybe, perhaps', ${ }^{17}$ while budze 'will be' is used as an auxiliary in the formation of the periphrastic future of imperfective verbs. These forms, when used in these special quasi-verbal or adverbial meanings, can be viewed as frozen forms which retain the more archaic ending. Because speakers viewed them more as independent 
lexemes rather than full-fledged members of the verbal system, može and budze failed to undergo the change that added $-t^{\prime}$ to the $3 \mathrm{~s}$ of 1 conj verbs. Russian dialectologists report similar phenomena from North and Central Russian dialects. ${ }^{18}$

More significant is the fact that the isoglosses which delimit 1conj $3 \mathrm{~s}$ $-e \emptyset$ and $/-e t^{\prime} /{ }^{19}$ are part of a series of thick isogloss bundles which transsect the Byelorussian language area from the Lithuanian to the Russian borders, and separate the SW dialect group from the NE. ${ }^{20}$ In the majority of cases, the more archaic member of an opposition survives on the SW side of the isogloss, while the $\mathrm{NE}$ one represents an innovation. The fact that the NE Byelorussian dialect group is generally more innovative than the SW suggests that 1 conj $3 \mathrm{~s}-e t^{\prime}$ is younger than $-e \emptyset .^{21}$

\section{Evidence for the Age of the Byelorussian 3s Isogloss}

The compactness of the Central Byelorussian bundles, and the number of isoglosses in them, point to a major break in communication in the East Slavonic language continuum. Furthermore, the relative ages of those isoglosses which can be dated accurately demonstrate that this break arose quite long ago, and was long-standing. For instance, an isogloss demarcating the consistent operation of the rule $e \rightarrow 0$ (NE) vs. inconsistent occurrence of this change (SW) corresponds almost exactly with the 3s isoglosses; linguists agree that this shift took place around the time of the fall of the jers in East Slavonic (12th-13th cents) ${ }^{22}$ On the other hand, another isogloss parallel to the 3s ones sets off different endings in the stem-stressed plural of certain neuter nouns: s'oly 'villages' (NE) vs. s'óla (SW). The NE variant is the result of an innovation which took place no later than the 15th century. ${ }^{23}$

Extralinguistic data suggest a similar time-frame, but make it extremely hard to set an outer limit in the early historical period. As far as can be determined, the Central Byelorussian bundles correspond quite well to the southernmost extent of the Western Krivichians, one of the tribes of pre-Kievan Eastern Slavdom. ${ }^{24}$ This in turn was the southern border to the Polotsk and Smolensk principalities - two Kievan-era states which arose in Western Krivichian lands and whose history was marked by extensive and intensive contacts. ${ }^{25}$

Hence, the isoglosses in question twined themselves around an ethnic and political frontier which goes back to prehistoric times. This frontier remained in existence until the Grand Duchy of Lithuania conquered Byelorussian territory in the 14th and 15th centuries. This, coupled with migrations from the south prompted by the Tatar invasion, opened up contacts between northern and southern Byelorussia, across the old boundary. ${ }^{26}$ Thus, the changes symbolized by these isoglosses are probably, like the s'oly: s'ola opposition discussed above, no older than the 15 th century. They can, however, date back to prehistory.

Let us then look in the opposite geographical direction - into the Russian language area. Most features which set the NE Byelorussian 
dialect group apart from the SW dialects can also be found to a greater or lesser extent in Russian dialects. We can distinguish three groups of such features: those which NE Byelorussian shares with Western Russian; those which it shares with the South Russian dialect group as a whole; and a much smaller set of features which binds NE Byelorussian with the North Russian dialect group.

The first two sets are quite large, and have often been discussed in the literature. ${ }^{27}$ Among the features shared by both NE Byelorussian and Western Russian are: initial $/ j /$ in the nominative of the masculine third-person pronoun (jon), and the ending $-y$ in the nominative of the third-person plural pronoun $(a n y \sim j a n y \sim j e n y) .{ }^{28}$ Map 1 shows a representative isogloss: the innovation involves a new stress pattern in the singular of certain feminine nouns. The original pattern - stem stress in the accusative (e.g., rúku 'hand'), end stress otherwise (n. ruká, g. ruki, etc) - has been simplified to end stress throughout the singular (thus, a stress shift in the accusative: rukú). ${ }^{29}$

$\mathrm{NE}$ Byelorussian shares a host of important features with the South Russian dialect group, for instance: voiced velar fricatives $/ \gamma /$ instead of $/ g /$; an $/ r /$ unpaired for hardness-softness; and advanced vowel-reduction systems generally referred to by the term akan'e. Map 2 shows isoglosses for two morphological innovations connected with vowel reduction. ${ }^{30}$

Linguists have long noted the connections between dialects of the extreme north and east of the Byelorussian language territory and the North Russian dialects of Pskov and Novgorod. ${ }^{31}$ These connections are hardly unexpected, given the common Krivichian background of Pskov and NE Byelorussian, and the cultural ties between Novgorod and these regions just to the south. However, features which bind NE Byelorussian and the North Russian dialect group as a whole are quite rare. 1 conj $3 \mathrm{~s}$ in $-t$ - is one such feature. ${ }^{32}$. See map 3.

Now, how can we interpret these facts? If we consider these linguistic data in the light of political history, it makes sense to assume that those innovations which NE Byelorussian shares with West Russian are the youngest. The shaded area in map 1 corresponds extraordinarily well to the area encompassed by the Polotsk and Smolensk principalities in the 12th century (as presented by the Bol'šaja Sovetskaja Enciklopedija). ${ }^{33}$ The eastern 'stress-pattern' isogloss, which passes midway between Smolensk and Moscow, runs close to the old border between the Grand Duchy of Lithuania and Muscovy. Thus, innovations such as the new stress pattern in nouns such as ruká probably reached their furthest eastern extent some time after the 14th century, when this political frontier could have impeded communication between the Polotskians and Smolenskians, and their brethren to the east.

The nature of the relationship between NE Byelorussian and South Russian is somewhat more controversial. The traditional view is that South Russian features such as akan'e were brought into what is now Northern Byelorussian by refugees from Rjazan' fleeing the Mongol 
hordes in the 13th-14th centuries. ${ }^{34}$ Opposing this view, George Shevelov has argued that akan'e (and other features) originated in Northern Byelorussia and travelled southeast as Krivichian settlers moved into recently depopulated regions of South Russia. ${ }^{35}$ At any rate, the timeframe is similar - the movement would have had to occur in the 13th15 th centuries.

The innovative 1conj 3s endings obviously travelled along a different route. They cover the same territory as the old West Krivichian principalities, but they seem to have burst through to the northeast over a corridor which runs between Novgorod and Moscow.

We propose, based upon this geographical configuration and the evidence of the manuscript tradition, that the addition of $-t \bar{\imath}$ to 1 conj $3 \mathrm{~s}-e$ was an innovation in the Krivichian dialect of the pre-Kievan tribal era. It is well-documented that 'Krivichia' extended north of Moscow into the Volga region around Kostroma ${ }^{36}$ This is the avenue that could have taken the new ending into the northeastern frontier of old Rus ${ }^{\prime 37}$

When literacy first came to the Eastern Slavs, 1conj 3s -eti was wellestablished, but probably existed side-by-side with $-e \emptyset$ in some areas. The old form, like today, no doubt persisted among conservative elements in the population and in frozen, quasi-verbal expressions. $\emptyset$ still prevailed in the peripheral dialects of the northwest, and in dialects spoken to the south and east of Polotsk and Smolensk. Hence, the mix of 1 conj $3 \mathrm{~s}$ forms in Old Russian documents. Later, starting in the 13th century, the $-t^{\prime}(\longleftarrow t \bar{\imath})$ of 3pers endings hardened in North Russian.

\section{Conclusions}

The facts of linguistic geography suggest that Birnbaum was wrong when he stated that different 3pers endings could not be used as distinguishing features of Common Slavonic dialects. We have reviewed evidence that Late Common Slavonic dialects spoken over the Russian plain were differentiated by (among other things) different 3s endings in the 1conj. This in turn makes plausible the claim that the other systems of 3pers 1conj and 2conj endings (there are two: East South Slavonic and West South Slavonic) ${ }^{38}$ must have also become distinct in Common Slavonic times. Much work still needs to be done, but we believe that this is the course which should be pursued in future research.

Byelorussian dialectology also corroborates what has long been held by historical linguists: that modern Byelorussian represents a partial fusion of two distinct ancient east Slavonic dialects. ${ }^{39}$ The more northerly of these dialects was the language of the West Krivichians. By comparison with the system which underlies modern SW Byelorussian (which receives various names in the literature), ${ }^{40}$ this dialect was vigorous and innovative. In all the features we have considered in this article, the NE dialect group is the innovator; and many more such features could be cited, as well.

Many 'Krivichian' innovations spread over what is now Russian terri- 
tory. 1conj 3s -etı̌ progressed into East Krivichian territory before the era of feudal principalities, and thus became a feature of North Russian dialects. Later there was a lively 'cross-pollination' between Polotsk and Smolensk dialects, and those spoken to the south of Moscow, although it may now not always be easy to tell in which direction the innovations travelled. Still later changes were confined to the Smolensk region, as the Lithuania-Moscow frontier hindered further eastern progression.

Let us here tentatively propose that there was an ancient innovative centre in the Krivichian lands around Smolensk. The influence of this centre extended to the western and southern borders of old 'West Krivichia' in what is now central Byelorussia; the eastern extent of this influence varied according to the political situation of any given period.

\section{NOTES}

1. In many Slavonic dialects a so-called 'third conjugation' has developed through the loss of intervocalic $-j$ - in 1conj verbs formed with the suffix $-a j$-. Since this is a comparatively late phenomenon with no direct bearing on the present discussion, we shall be ignoring the third conjugation in this article. Nor shall we crnsider the small class of Slavonic athematic verbs.

2. A summary of difff $\llcorner$ eint views can be found in Raymond $H$. Miller, 'The Geographical Distribution of Present-Tense Endings in Byelorussian Dialects' (unpublished doctoral dissertation, Harvard University, 1980), pp.41-55.

3. Variation within the third-person plural [3p] is comparatively recent in Byelorussian dialects (see Miller, op.cit., ch. 5). In our view, the history of the 2conj 3s in Slavonic is inextricably bound up with the history of the 2 conj itself, and is thus beyond the scope of this article. See Miller, op.cit., pp.56-57. (And, once again, what variation we see in East Slavonic is demonstrably late.)

4. F.P. Filin, Obrazovanie russkogo, ukrainskogo i belorusskogo jazykov, Leningrad, 1972, pp.444-48.

5. ibid., p.448.

6. For the 3pers in Ukrainian dialects, see: S.P. Bevzenko, Istorycna morfolo$l$ ia ukrains'koji movy, Užhorod, 1960, pp.278-86; Ja. V. Zakrevs ka, 'Systema osobovyx form dijeslova v zaxidnyx hovorax ukrains koji movy', in Ukrajins'ka linhvistyčna heohrafija, ed. F.T. Žylko, Kiev, 1966, pp.119-32; and N.T. Marcuk, 'Formy 3-iji osoby dijesliv teperišn'oho casu v ukrajins kyx hovorax' in Ukrajins'ka dialektna morfolohija, ed. F.T. Žylko, Kiev, 1969, pp.168-77.

7. See Russkaja dialektologija, ed. R.I. Avanesov and V.G. Orlova, Moscow, 1964, p.161; Obrazovanie severnorusskogo narečija i srednerusskix govorov, ed. V.G. Orlova, Moscow, 1970, pp. 125-27; Filin, op.cit., pp.438-39; S.P. Obnorskij, Ocerki po morfologii russkogo glagola, Moscow, 1953, pp.122-25.

8. Russkaja dialektologija, pp.162-63; Obrazovanie severnorusskogo narečija i srednerusskix govorov, pp.196-99; Filin, op.cit., p.440; Obnorskij, op.cit., pp.118-21. Forms in hard $t$ start appearing regularly in North Russian documents in the 13th-14th centuries: Obnorskij, op.cit., pp.130-31; Filin, op.cit., p.444.

9. See Dyjalektatahičny attas biełaruskaj movy, ed. R. I. Avaniesaú et al., 
Minsk, 1963, maps 148, 149; also Ju. F. Mackievic, Marfałohija dziejastova ú biełaruskaj movie, Minsk, 1959, pp.118, 121. Both works contain copious amounts of data; more data can be culled from the texts in Chrestamatyja pa biełaruskaj dyjalektałohii, ed. R.I. Avaniesaŭ and M.V. Biryła, Minsk, 1962.

10. See discussion in Miller, op.cit., pp.42-49.

11. For example, F. Meillet, Le Slave Commun, Paris, 1934, pp.319-21; C.S. Stang, Das Slavische und Baltische Verbum, Oslo, 1942, p.216.

12. See P.S. Kuznecov, 'Pis'mo v redakciju', Voprosy jazykoznanija, 3, 1955, pp.136-39. $\varnothing$ endings in Slavonic, it should be pointed out, can go back to Indo-European [IE] endings either in $\emptyset$ or a final consonant; it was Kuznecov's feeling that 3 pers $\emptyset$ endings in modern Slavonic dialects ultimately go back to a mixture in early Slavonic times of the primary endings in -t $t \grave{~(u s e d ~}$ in IE for the present tense) and the secondary endings in - $t$ (used in IE for the preterite tenses and the injunctive mood), which, of course, dropped in Slavonic through the law of open syllables. See Kuznecov, op.cit., p.138.

13. For example, Mackievic, op.cit., p.131.

14. H. Birnbaum, 'The Dialects of Common Slavic', in Ancient Indo-European Dialects, ed. H. Birnbaum and J. Pahvel, Berkeley, 1966, pp.181-83.

15. Filin, op.cit., p.449. See also F.M. Jankoŭski, Histaryčnaja hramatyka biełaruskaj movy, Minsk, 1983, p.191.

16. Miller, op.cit., pp.7-11, esp. table 4.4, p.9.

17. See texts in Chrestamatyja pa bietaruskaj dyjalektatohii, e.g. the one for the village of Bažki (p.14): 'žýl'i my tam tak móža n'aźiél' j́ve-try. . '

18. Obnorskij, op.cit., pp.119-21, 123-25.

19. There are two: one for 1conj verbs marked for end stress, and one running slightly to the north of the first for 1conj verbs not so marked; see Dyjalektałahičny attas bietaruskaj movy, maps 148, 149.

20. See Linhvistyčnaja heahrafija i hrupoūka bietaruskich havorak, ed. R.I. Avaniesaŭ et al., Minsk, 1968-69, vol.1, maps 16, 18, 20, 21, 49; vol.2, pp.4149, 51-59 (esp. 56-59), 207-23, 230-46 (esp. 232-33). Also see the appropriate maps in Dyjalektatahičny attas bietaruskaj movy.

21. This is a generally acknowledged fact in Byelorussian linguistics; see Linhvistyčnaja heahrafija i hrupoŭka bielaruskich havorak, vol.2, p.243 (but cf. R.I. Avanesov, 'Voprosy obrazovanija russkogo jazyka v ego govorax', Vestnik MGU, 9, 1947, p.131).

22. See maps in M.V. Biryła, 'Vyniki pierachodu e (๘e, i) u o i źjavy, źviazanyja z im u biełaruskaj movie', Prace Filologiczne, vol.XVU, 2, 1964, pp.315-34; also text, p.334.

23. Linhvistyčnaja heahrafija i hrupoŭka biełaruskich havorak, vol.2, p.238.

24. See, for example, J. Serech (George Shevelov), Problems in the Formation of Belorussian, special supplement to Word, vol.9, Dec.1953, pp.61, 91; Avanesov, op.cit., pp.123, 134. Cf. map in Bol'saja Sovetskaja Enciklopedija under 'Kievskaja Rus".

25. Avanesov, op.cit., pp.128, 134-35.

26. ibid., pp.134-35; Šerech, op.cit., pp.56, 58-59. The Avanesov article, incidentally, contains a valuable critique of earlier theories of the formation of Byelorussian, most notably those of Šaxmatov.

27. Avanesov, op.cit., p.135; Šerech, op.cit., pp.69, 73-74, 77; Linhvistyênaja heahrafija i hrupoŭka bietaruskich havorak, vol.2, pp.217-19. 
28. ibid., vol.2, p.217.

29. See ibid., vol.1, map 18 and Obrazovanie severnorusskogo narečija $i$ stednerusskix govorov, pp.403-04 (esp. map 108 on p.404). Map 1 is a composite of these two maps.

30. See Linhvistyčnaja heahrafija i hrupoŭka biełaruskich havorak, vol.1, maps 18 and 52; vol.2, p.130; and Obrazovanie severnorusskogo narečija $i$ srednerusskix govorov, pp.150-53 (esp. maps 41 and 42).

31. Linhvistyčnaja heahrafija i hrupoüka bielaruskich havorak, vol.2, pp.22330; Šrech, op.cit., pp.55ff.; Avanesov, op.cit., p.135.

32. Although the desinence-final $-t$ is hard in North Russian, there is sufficient evidence to assume that it was originally the same soft $-t^{\prime}$ we see in Byelorussian, Ukrainian and South Russian. See Obnorskij, op.cit., pp.119ff.

33. See article on 'Kievskaja Rus".

34. Avanesov, op.cit., pp.132-34.

35. Serech, op.cit., pp.70-78 et passim.

36. Avanesov, op.cit., p.128; Linhvistyčnaja heahrafija i hrupoŭka biełaruskich havorak, vol.2, p.222.

37. Avanesov (op.cit., p.125, fn.1) has rightly warned that one should avoid seeing tribal-era dialectal oppositions in modern isoglosses. However, we believe that, in this case, one can and should.

38. West South Slavonic (Slovene and Serbo-Croatian) and West Slavonic have a $\emptyset$ in all 1conj, 2conj and 3conj 3pers forms. East South Slavonic (Macedonian and Bulgarian) has $\emptyset$ in the $3 s,-t$ in the 3p (we cannot tell today whether this $-t$ came from original *-t $\check{\imath}$ or ${ }^{*}-t \bar{u}$ ). Of all the West and South Slavonic languages, only Macedonian and Bulgarian show dialectal variation in the shape of the 3pers desinences. See Miller, op.cit., p.37. Presentday variation suggests an ancient East-West split in Common Slavonic dialects, with the Eastern Common Slavonic dialects subsequently splitting into southern (Bulgaro-Macedonian) and northern (East Slavonic) groups. The East Slavonic innovation discussed in this article would then have occurred towards the end of the Common Slavonic period. See Miller, op.cit., pp.55-60 for discussion; also see map 4.6 on pp.38-9.

The $-t \bar{u}$ of the Old Church Slavonic canon presents a nest of problems for the language historian. It is in no way connected with the similar North Russian ending, and should probably be viewed merely as an innovation of those Bulgaro-Macedonian dialects which underlie Old Church Slavonic (Miller, op.cit., pp.61-63).

39. This is essentially the point of Šerech's monograph. See especially his conclusion, and the chart on p.93. Also see Avanesov, op.cit., pp.134-35. The same claim can be found in many recent works of Byelorussian dialectology, as well.

40. Šerech, for instance, calls this ancient dialect the 'Kiev-Polesie' dialect, while Avanesov simply refers to the principalities in which this was spoken (Turov-Pinsk, Črnaja Rus). 


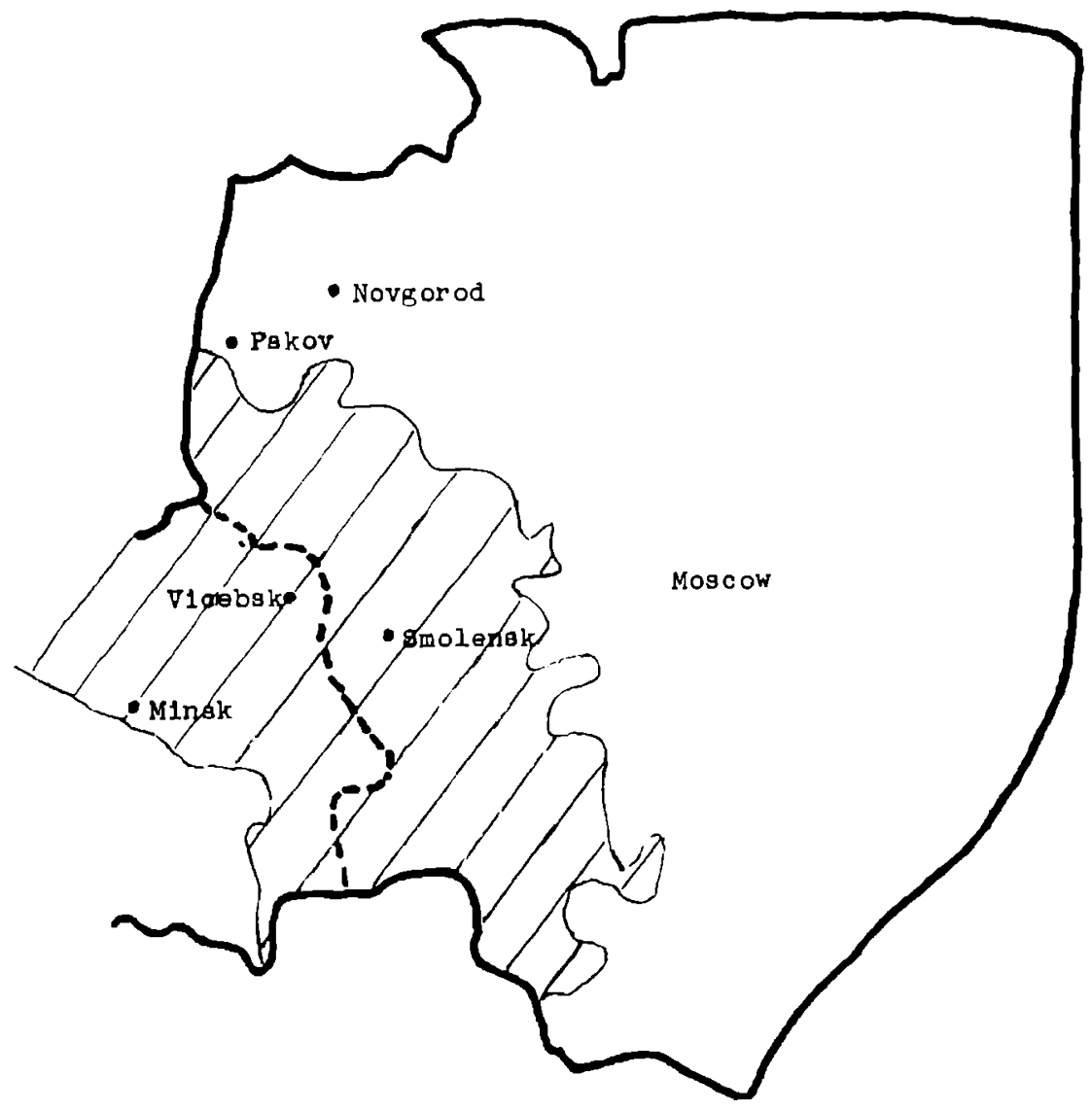

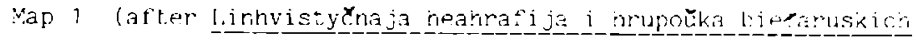
havorak, ed. f.l. Avaniesaŭ et al., vol. h, Minsk, 1968 , map 18 and Obrazovanie severnorusskogo rare $\ell_{i}$ ja i

srednerusskix govorov, ed. V.C. Orlova, Moscon, 19?J, map $108, p .404$ )

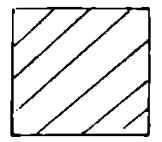

Entire singular paradigm marked :or ond stress in certain seminine rour!s; ค.g., r. ruká, g.rlkkí, ‥ a. rukú. 


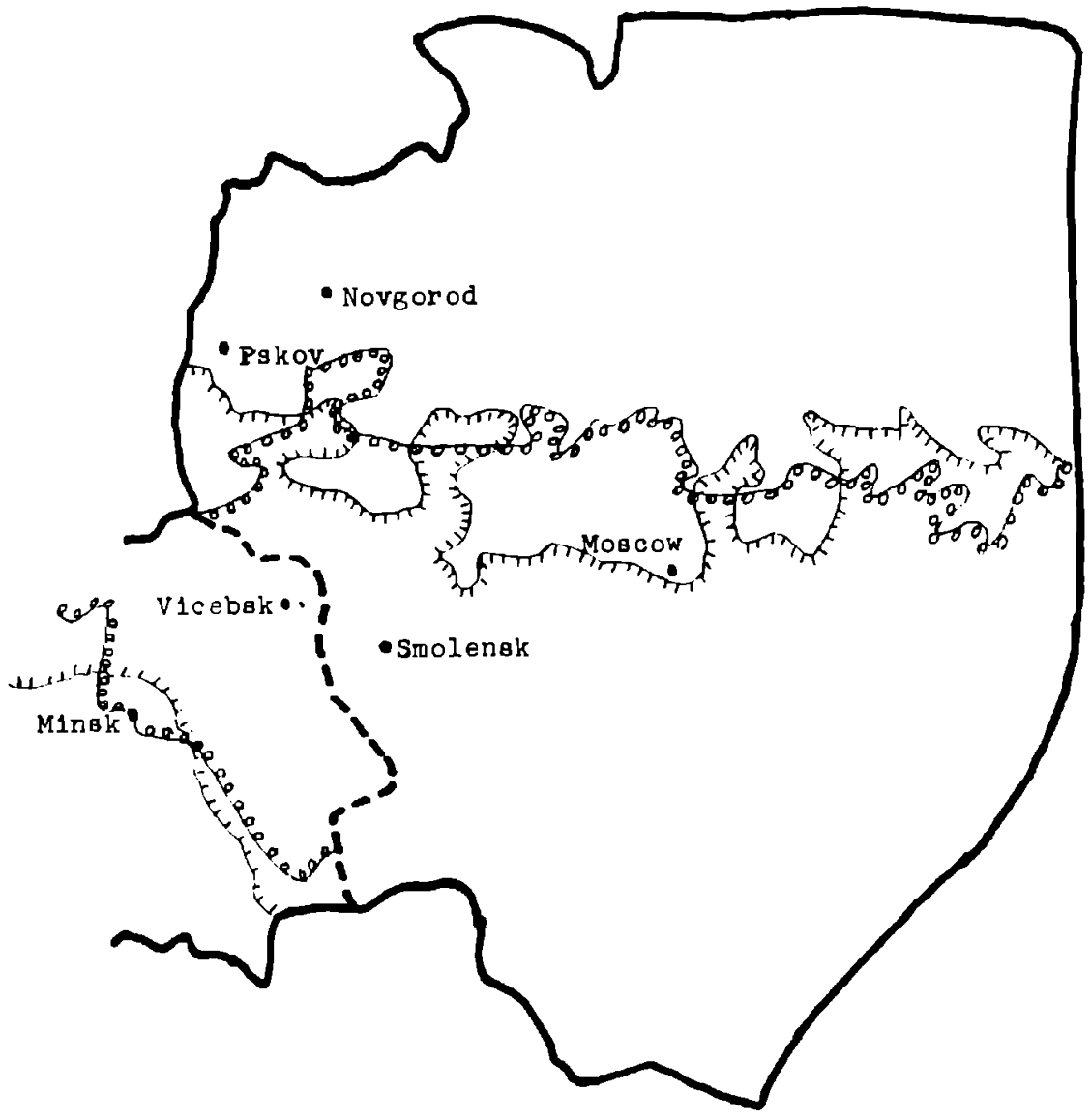

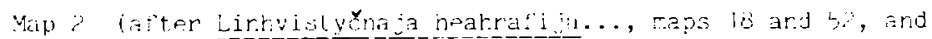

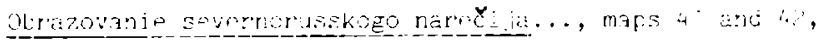
pp. 151, 13:

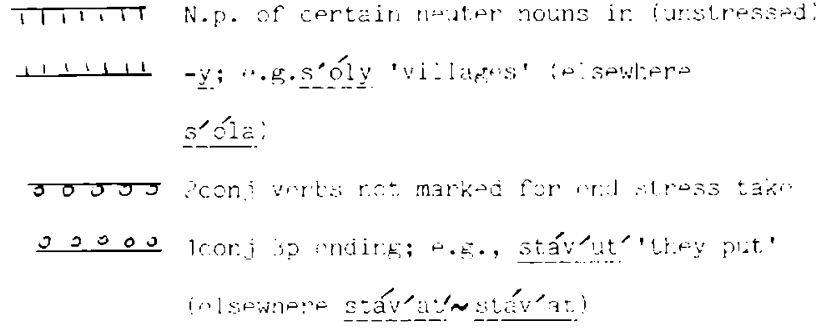




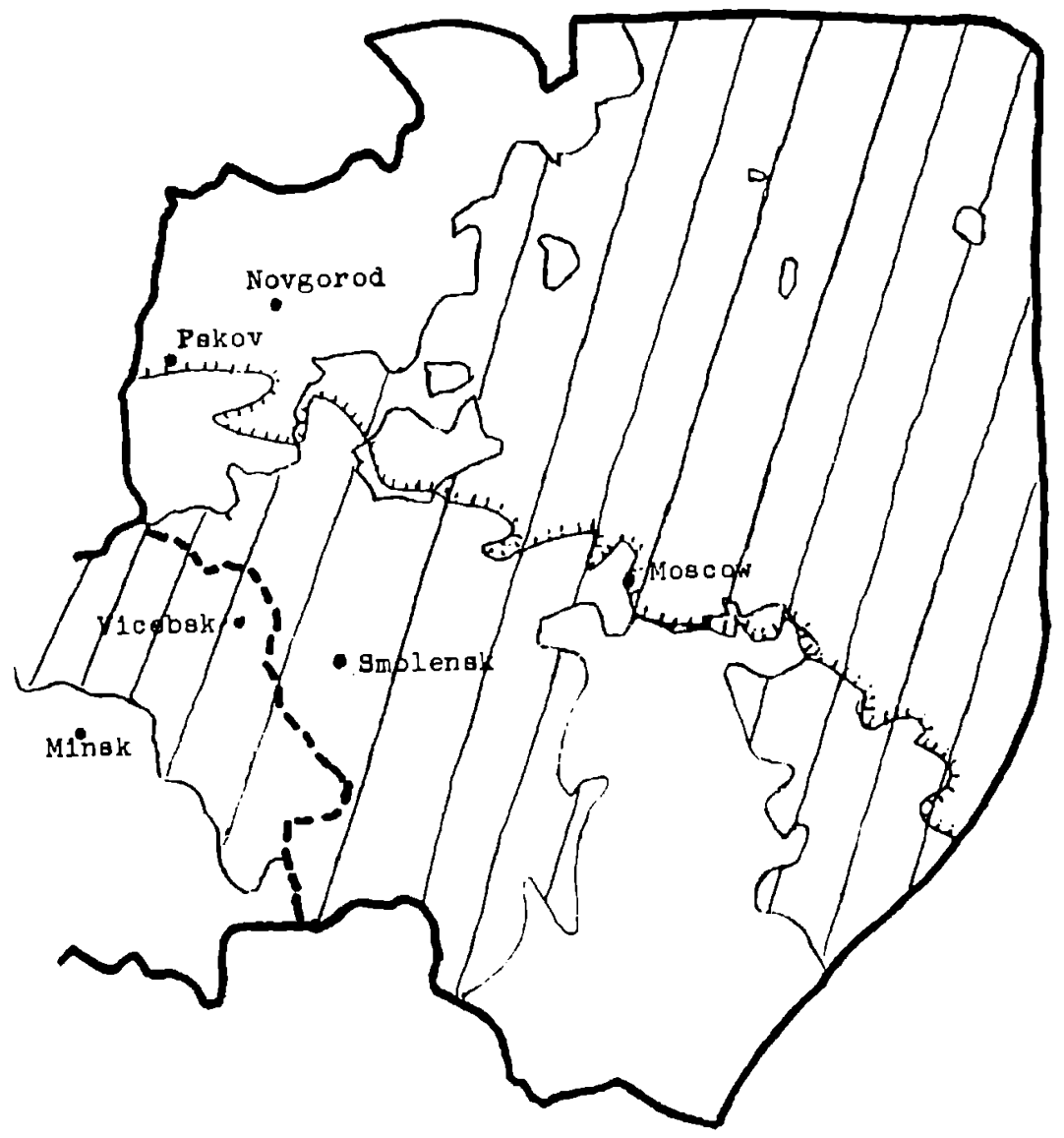

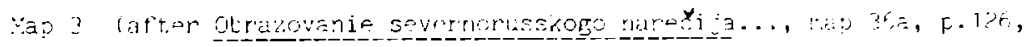

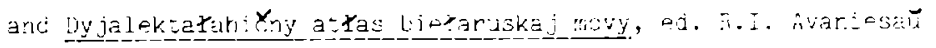

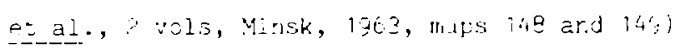

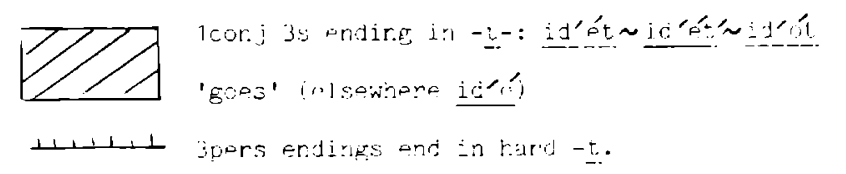

